\title{
Mindfulness Regarding the Health Benefits of Basil (Tulsi) Leaves
}

\author{
Dr. Payal Mahajan ${ }^{1}$, Dr. Suhani Sinha², Dr. Jyoti Goyat ${ }^{2}$, Dr. Garima Singh ${ }^{2}$, Dr. Deepak Sharma ${ }^{2}$ \\ ${ }^{1} \mathrm{HOD}$, School of Medical \& Allied Sciences, GD Goenka University, Gurgaon, Haryana, India \\ ${ }^{2}$ Assistant Professor, School of Medical \& Allied Sciences, GD Goenka University, Gurgaon, India
}

\begin{abstract}
Article Info

Volume 8, Issue 4

Page Number : 486-490

\section{Publication Issue}

July-August-2021

\section{Article History}

Accepted : 02 Aug 2021

Published : 08 Aug 2021

Historically, the leaves of Basil plant are being consumed by a significant population. It has been regarded as the sovereign of all spices, well-known for its recuperating properties. Current research study offers amazing proof that Basil decreases blood pressure, upgrades endurance, mitigates irritation, brings down cholesterol, wipes out poisons, ensures against radiation, forestalls gastric ulcers, brings down fevers, improves processing and gives a rich stock of cancer prevention agents and different supplements. Basil is particularly compelling in supporting the heart, veins, liver and lungs and furthermore controls pulse and glucose. To assess the awareness of people regarding the importance of basil leaves, the present research has been conducted. The sample of present study consists of 100 young, adults and elderly person. The objectives of the research are to assess the knowledge regarding the health benefits of basil leaves; to know the sources of information \& to identify facts about health benefits of basil leaves. Random sampling techniques was used to select the sample. The sample of present study consists of young, adults and elderly person in the age group of 18-50 years only. Questionnaire was used to collect the information. After the collection of data, coding will be done systematically and analysis will be done thereafter.
\end{abstract}

Keywords : Basil Leaves, Tulsi, Medicinal

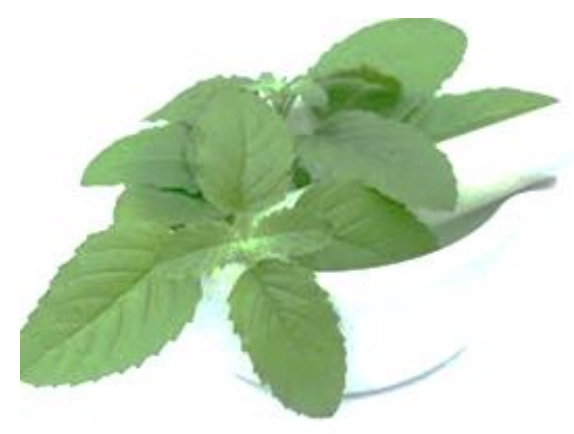

\section{INTRODUCTION}

Basil o (/'bæzəl/, also US: /'beizəl/; Ocimum basilicum), also called great basil, sa culinary herb of the family Lamsiaceae (mints). Basil (Indian name-Tulsi) is an aromatic perennial plant in the family Lamiaceae. It is native to the Indian subcontinent and widespread as a cultivated plant throughout the Southeast Asian tropics. 
Basil is cultivated for religious and traditional medicine purposes, and for its essential oil. It is widely used as a herbal tea, commonly used in Ayurveda, and has a place within the Vaishnava tradition of Hinduism, in which devotees perform worship involving holy basil plants or leaves. Basil is native to tropical regions from central Africa to Southeast Asia. It is a tender plant, and is used in cuisines worldwide. Depending on the species and cultivar, the leaves may taste somewhat like anise, with a strong, pungent, often sweet smell. There are many varieties of basil, as well as several related species or hybrids also called basil. Basil has got the great medicinal value. Basil has for some time been utilized in culinary customs, yet its set of experiences is rich with different utilizations in the public arena. In antiquated Egypt, basil was likely utilized as a treating and safeguarding spice as it has been found in burial chambers and mummies. Maybe as a result of its preserving applications, basil was likewise an image of grieving in Greece where it was known as basilikon phuton, which means sublime, regal, or royal spice. Basil additionally has a solid history in antiquated customary meds like Ayurveda, the conventional restorative arrangement of old India, notwithstanding other therapeutic natural practices. Basil additionally brought assorted social and emblematic significance through history. For example, in Jewish fables basil is accepted to add strength while fasting. In Portugal, basil plants make up piece of a blessing to a darling or sweetheart on certain strict occasions. Though in old Greece, basil represented scorn. These are nevertheless a couple of instances of the enduring social significance of the spice.

\section{MEDICINAL PROPERTIES}

Basil is antispasmodic, starter, carminative, galactagogue, and stomachic. It is utilized for stomach cramps, gastric catarrh, heaving, intestinal catarrh, obstruction, and enteritis. It had been now and then utilized for outshining hack as an antispasmodic.
Basil has antioxidant properties and reduces blood glucose levels. Thus it is useful for diabetics.

> Basil reduces total cholesterol levels. Thus it is useful for heart disease patients.

$>$ Basil reduces blood pressure.

Basil is also used to prepare herbal tea. It helps in building up stamina.

It has been used for gastric disorders, cough, common colds, malaria, and headaches.

$>$ It is used as mouth wash for reducing tooth ache

$>$ Basil oil shows larvicidal activity against malarial larva.

$>$ It has immuno-modulatory properties

$>$ It contains phyto-chemicals which provide all these beneficial effects.

$>$ Many herbal cosmetics contain Basil. It is also used in skin ointments due to its anti-bacterial properties

Basil acts as insect repellant. So it is used to store grains.

$>$ Recent research shows that Basil does have analgesic (pain killer) properties similar to COX 2 inhibitor drugs.

$>$ It has antiviral, antibacterial, antitubercular, antifungal, antimalarial properties.

\section{BASIL USED AS TRADITIONAL INDIAN AYURVEDIC MEDICINE}

According to Organic India, an organization dedicated to organic agriculture and sustainable development, one of the qualities that make the Basil plant such a potent medicinal herb is its ability to reduce stress. Basil is abundant in essential oils and antioxidants, which are tremendously effective in reducing the effect of stress. On the body. Basil has got diverse healing properties. Though traditionally used by Hindus or Indians now others 
are using it too recognizing its immense therapeutic properties. The Basil has the property of acting as an adaptogen. It balances different processes in the body and is of great help in stress management

\section{BASIL IN MODERN MEDICINE}

There has been research demonstrating Basil may conceivably be a successful therapy for conditions like ulcers, elevated cholesterol, Type 2 diabetes, heftiness and bargained/stifled resistant frameworks (from conditions like malignant growths and AIDS). Plant Cultures says the conventional employments of Basil in Ayurveda may be because of some inborn properties in numerous assortments of Basil, for example, the fundamental oils containing a disease mitigating compound called eugenol, and different acids with cell reinforcement and calming properties that could uphold the cases of Basil being a treatment for such countless conditions, as indicated by Ayurveda.

\section{CHEMICAL NATURE OF BASIL LEAVES AND its USES}

The compound organization of Basil is extremely complicated. It is eugenol or 1-hydroxy-2-methoxy4 -allylbenzene. This synthetic equation contains numerous phyto-synthetic substances alluded as mixtures. These various mixtures present in whole plant comprise of cell reinforcement, adaptogenic, and mitigating, antibacterial and invulnerable improving properties. With these properties when anybody devours Basil in any form their body gets arranged to battle against the infections and other medical conditions.

Research Methodology The sample of present study consists of young, adults and elderly person. The objectives of the research are to assess the knowledge regarding health benefits of basil leaves; to know the sources of information \& to identify facts about health benefits of basil leaves. The sample of the present research were 100 young and elders goers. Random sampling techniques was used to select the sample. The sample of present study consists of young, adults and elderly person in the age group of 18-50 years only. Questionnaire was used to collect the information. After the collection of data, coding will be done systematically and analysis will be done thereafter

\section{RESULTS}

\begin{tabular}{|c|c|c|}
\hline Questions & Yes & NO \\
\hline Have $\mathrm{u}$ heard about basil leaves? & $95 \%$ & $5 \%$ \\
\hline $\begin{array}{l}\text { Are you aware about the Indian name } \\
\text { of basil leaves? }\end{array}$ & $85 \%$ & $15 \%$ \\
\hline \multicolumn{3}{|l|}{ Why it is called Holy basil? } \\
\hline Because of Hindu mythology... & $45 \%$ & \\
\hline Because people worship... & $37 \%$ & \\
\hline Because of its medicinal value.... & $18 \%$ & \\
\hline Do you have a basil leaf plant at home & $86 \%$ & $14 \%$ \\
\hline \multicolumn{3}{|l|}{$\begin{array}{l}\text { Who recommended you to keep basil } \\
\text { leaf plant at home }\end{array}$} \\
\hline Parents.................................. & $55 \%$ & \\
\hline 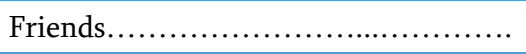 & $33 \%$ & \\
\hline Religion.................................... & $9 \%$ & \\
\hline No one/Self recommended....... & $3 \%$ & \\
\hline Is basil leaf good for health? & $97 \%$ & $3 \%$ \\
\hline Do you think it has medicinal value? & $97 \%$ & $3 \%$ \\
\hline $\begin{array}{l}\text { Do you ever use or consume basil } \\
\text { leaves? }\end{array}$ & $93 \%$ & $7 \%$ \\
\hline $\begin{array}{l}\text { Do you think we can eat basil leaves } \\
\text { raw? }\end{array}$ & $71 \%$ & $29 \%$ \\
\hline \multicolumn{3}{|l|}{$\begin{array}{l}\text { In which way you consume basil } \\
\text { leaves? }\end{array}$} \\
\hline Soup.............................. & $9 \%$ & \\
\hline Tea............................... & $69 \%$ & \\
\hline Concoction (Kadha)......... & $22 \%$ & \\
\hline Grounded form................ & $8 \%$ & \\
\hline Does basil leaves increase body heat? & $47 \%$ & $53 \%$ \\
\hline $\begin{array}{l}\text { Do you know about medicinal } \\
\text { properties of basil leaves? }\end{array}$ & $88 \%$ & $12 \%$ \\
\hline Do you think it has any side effects? & $33 \%$ & $67 \%$ \\
\hline $\begin{array}{l}\text { Would you ever use basil leaves on } \\
\text { skin. }\end{array}$ & $74 \%$ & $26 \%$ \\
\hline
\end{tabular}

It is apparent from the above table that $95 \%$ of the absolute sample were mindful about basil leaves; 
greater part of them knew with its Indian name; $45 \%$ of them consider basil leaves (tulsi) as heavenly in light of our Hindu approach; 37\% of them accept that on the grounds that our antecedents worship something very similar so they think of it as sacred anyway just $18 \%$ of them consider it a blessing in light of the fact that it has healing qualities.

Greater part of the sample expressed that their parents directed them to have tulsi at home, 33\% were directed by their companions about its importance; $9 \%$ follows the equivalent in light of their religion. Surprisingly almost all (97\%) accepts that basil leaf is useful for wellbeing as it has restorative qualities and consumes basil leaves, and 71\% of them expressed that they consume crude basil leaves in their everyday life; Greater part of them devour in tea, streamed by kadha, trailed by soups and others

INTERVENTION After scrutinizing the information and mindfulness in regards to the medical advantages of basil leaves, we track down that $94 \%$ of the greater part think about the medical advantages of basil leaves. The 97\% larger part know it's useful for wellbeing and having therapeutic qualities among these there are $93.1 \%$ individuals utilize or devour the basil leaves. The $85 \%$ larger part of individuals burn-through as tea and $68 \%$ of individuals use in kadha (Ayurvedic soup). Most of individuals realize that it fixes illnesses like fever, normal cold, Headache, hack, kidney sicknesses, and respiratory sicknesses like asthma, mouth contamination, skin issue, eye issues, flu, hypertension, heart issues, and diabetes. 5 to $6 \%$ of individuals don't have the foggiest idea, what basil leaf is. Furthermore, the individuals who understand what it is don't have the appropriate information on it. So we assumed the liability to mindful others of the medical advantages of basil leaves and the day by day employments of basil leaves. We make it conceivable by spreading banners that contain learned realities and medical advantages with respect to basil leaves. They have been educated with the right data in regards to some clinical benefits of basil leaves entitled "The Health Benefits of Basil Leaves" wherein they have been informed that Basil leaves helps in following ways: treatment of asthma, cough and cold; prevents bad breath; promotes dental health; boosts immunity; protects internal organs; prevents cancer; reduces risk of kidney stones; skin care and healthy hair; reduces stress \& prevents premature ageing

\section{HEALTH BENEFITS OF BASIL (TULSI) IN OUR DAILY LIFE}

Improving Power: The Basil plant has numerous restorative properties. The leaves are a nerve tonic and furthermore sharpen memory. The leaves reinforce the stomach and incite extensive sweat. The seed of the plant are adhesive.

Fever and Common Cold: The leaves of basil are explicit for some fevers. In the event of intense fevers, a decoction of the leaves overflowed with powdered cardamom into equal parts a liter of water and blended in with sugar and milk cuts down the temperature.

Sore Throat: Water overflowed with basil leaves can be taken as drink in the event of sore throat. This water can likewise be utilized as a swish.

Respiratory Disorder: The spice is helpful in the treatment of respiratory framework problem.

Kidney Stone: Basil has reinforcing impact on the kidney. If there should be an occurrence of renal stone the juice of basil leaves and nectar, whenever taken routinely for a half year it will remove them by means of the urinary lot.

Heart Disorder: Basil has an advantageous impact in cardiovascular infection and the shortcoming coming about because of them. It diminishes the degree of blood cholesterol. 
Youngsters' Ailments: Common pediatric issues like hack cold, fever, looseness of the bowels and regurgitating react well to the juice of basil leaves.

Stress: Basil leaves are viewed as an 'adaptogen' or hostile to stretch specialist. Indeed, even solid people can bite 10-12 leaves of basil, double a day, to forestall pressure. It decontaminates blood and forestalls a few normal components.

Mouth Infections: The leaves are very successful for the ulcer and contaminations in the mouth. A couple of leaves bit will fix these conditions.

Skin Disorders: Applied locally, basil juice is helpful in the treatment of ringworm and other skin illnesses. It has likewise been attempted effectively by certain naturopaths in the treatment of leucoderma.

Teeth Disorder: The spice is helpful in teeth problems. Its leaves, dried in the sun and powdered, can be utilized for brushing teeth. It can likewise be blended in with assembled oil to make a glue and utilized as toothpaste.

Cerebral pains: Basil makes a decent medication for migraine. A decoction of the leaves can be given for this problem.

Eye Disorders: Basil juice is an exciting solution for sore eyes and night-visual impairment, which is by and large brought about by lack of nutrient A. Two drops of dark basil juice are placed into the eyes every day at sleep time.

\section{CONCLUSION}

In the light of above research work, it very well may be derived that the arbitrary populace taking an interest in the examination, were aware of the medical advantages of tulsi, and larger part of them were at that point burning-through it in some structure or the other, ascribed to their own convictions, suppositions and mindfulness in regards to its therapeutic worth. The factual information reflecting wide utilization in various structures could be because of the way that this spice is Indigenous to the Indian subcontinent, has delighted in a huge presence in customary arrangement of drugs and strict practices for many years according to the reported confirmations, and henceforth require no clinical information to persuade individuals in regards to its wellbeing and viability profile for every one of the diseases specified in this article. 'Tulsi' is viewed as protected and viable for utilization detached structures by individuals on the loose.

\section{Cite this article as :}

Dr. Payal Mahajan, Dr. Suhani Sinha, Dr. Jyoti Goyat, Dr. Garima Singh, Dr. Deepak Sharma, "Mindfulness Regarding the Health Benefits of Basil (Tulsi) Leaves", International Journal of Scientific Research in Science and Technology (IJSRST), Online ISSN : 2395-602X, Print ISSN : 2395-6011, Volume 8 Issue 4, pp. 486-490, July-August 2021. Available at

doi : https://doi.org/10.32628/IJSRST218419

Journal URL : https://ijsrst.com/IJSRST218419 